\title{
Spatial gradients in dissolved carbon due to tidal marsh outwelling into a Chesapeake Bay estuary
}

\author{
Maria Tzortziou ${ }^{1,2, *}$, Patrick J. Neale ${ }^{2}$, J. Patrick Megonigal ${ }^{2}$, Crystal Lee Pow $^{2,3}$, \\ Megan Butterworth ${ }^{2}$
}

${ }^{1}$ University of Maryland, Earth System Science Interdisciplinary Center, College Park, Maryland 20742, USA

${ }^{2}$ Smithsonian Environmental Research Center, Edgewater, Maryland 21037, USA

${ }^{3}$ Carnegie Mellon University, Pittsburgh, Pennsylvania 15213, USA

\begin{abstract}
Tidal marshes have been previously shown to affect fluxes of carbon and nutrients in adjacent estuaries by acting as sources, sinks or transformers of compounds transported in water exchanged between the marsh and estuary. Relative to information on the amount and direction of these exchanges, much less is known about the distribution and fate of the distinctive dissolved organic compounds derived from marshes, and the spatial extent to which this 'marsh signature' affects optical and biogeochemical variability in the estuary. In the present study we address the spatial distribution of both dissolved organic carbon (DOC) and dissolved inorganic carbon (DIC), as well as other biogeochemical components, in the Rhode River estuary-marsh complex of the Chesapeake Bay. High-spatial-resolution transects showed that the marshes are a major source of DOC, DIC and $p \mathrm{CO}_{2}$ to the adjacent estuary and atmosphere, and that they seem to trap algae and other suspended particulate matter while releasing high-molecular-weight, aromatic-rich, highly colored dissolved organic matter (CDOM) into the estuary through tidal flushing. These processes result in strong variability in water characteristics considerably beyond the marsh-estuary interface. Non-conservative mixing in CDOM with salinity was probably due to both intense processing of the more labile marshexported components, as well as to mixing with other terrestrial and wetland inputs into the estuary. Despite the possible role of the adjacent subtidal mudflat as a sink for some of the material released from the marshes, the marsh signature was distinguishable from the regional estuarine background over a distance of more than $1 \mathrm{~km}$ into the river.
\end{abstract}

KEY WORDS: Carbon dynamics - Intertidal zone - Brackish marshes - Dissolved organic matter · Dissolved inorganic carbon $\cdot$ Optical properties $\cdot$ Biogeochemistry $\cdot$ Estuarine processes

\section{INTRODUCTION}

Located at the interface between aquatic and terrestrial environments, coastal tidal marshes are hot spots of biogeochemical transformation and exchange, affecting estuarine water quality, trophic structure and ecology. Dating back to the late 1950s, the Outwelling Hypothesis (Kalber 1959, Odum 1961, Teal 1962) proposed that highly productive salt marshes hydrologically export organic matter and nutrients to estuaries and coastal waters, providing food resources that support marine productivity in coastal systems. This hypothesis, although later challenged (Woodwell et al.
1977, Nixon 1980, Wiegert et al. 1981, Childers et al. 1993), was extensively used for conservation and management of the coastal zone. The potential for marsh areas to act as 'filters' that retain toxic substances and suspended sediments (Valiela et al. 1973, Sloey et al. 1978) provided another argument for salt marsh protection and restoration. These concepts about the role of tidal marshes as sources, sinks and transformers of nutrients, carbon and pollutants have since been tested by a number of studies in various marsh-estuarine environments and geomorphological settings (Nixon 1980, Dankers et al. 1984, Whiting et al. 1989, Dame et al. 1991, Dame 1994, Childers et al. 2000). 
Although there is no consensus on the magnitude and direction of total (including both particulate and dissolved) organic carbon exchanges between marshes and estuaries, most previous studies indicate that salt marshes export dissolved organic carbon (DOC) to the surrounding estuarine ecosystem (Nixon 1980, Dankers et al. 1984, Jordan \& Correll 1991, Childers et al. 2000). Moran et al. (1991) used lignin phenols (vascular plant biomarkers) to show that dissolved material derived from Spartina alterniflora plants in salt marshes can be the source of up to $36 \%$ of nearshore DOC and up to $20 \%$ of inner-shelf DOC along the Georgia coast. Based on measurements of lignin phenol concentrations, Moran \& Hodson (1994) estimated that from 11 to $75 \%$ of the dissolved humic substances on the southeastern USA continental shelf originate in vascular-plant-dominated environments, with about equal contributions from coastal salt marshes and river export. Using a stable-isotope tracer approach, Peterson et al. (1994) showed that Spartina patens-dominated salt marshes were a major source of DOC to Fourleague Bay in the Gulf of Mexico. Measurements of tidal exchanges of nutrients in the Rhode River subestuary of the Chesapeake Bay (Jordan et al. 1983) showed that, on a yearly basis, the brackish tidal marshes in this system act as transformers of particulate to dissolved matter, exporting DOC. Further studies by Tzortziou et al. (2008) in the same area revealed that water leaving the Rhode River marshes during ebbing tide is consistently enriched (more than 2-fold) in DOC relative to water entering the marsh during flooding tide. Estimates of DOC fluxes showed a net DOC export from the marsh to the estuary during seasons of both low and high marsh productivity.

Tidal marshes have also been shown to be sources of dissolved inorganic carbon (DIC) to adjacent waters, affecting the magnitude and direction of $\mathrm{CO}_{2}$ exchange between coastal waters and the atmosphere (Cai \& Wang 1998, Cai et al. 1999, 2000, Raymond et al. 2000, Neubauer \& Anderson 2003, Wang \& Cai 2004, Borges 2005). Cai et al. (2000) found that intertidal marshes in the Satilla River along the coast of Georgia are sites of intensive respiration that export DIC to the estuary. According to the authors, although only a small fraction (on the order of $10 \%$ ) of DIC generated in the marshes is exported to the coastal sea, it represents a nearly 3 -fold increase in riverine DIC flux to the ocean. Measurements by Neubauer \& Anderson (2003) in a Virginia tidal freshwater marsh-estuarine system showed that DIC concentrations near low tide were from 1.5- to 5-fold enriched compared to high tide concentrations, indicating an export of DIC from the marsh. When extrapolated to an estuary-wide scale, the export of marsh-derived DIC (in the form of carbonate alkalinity) to the York River estuary explained a significant portion (mean \pm SD: $47 \pm 23 \%$ ) of excess DIC production in this system.

Recent studies on the effects of tidal marshes on estuarine optical characteristics, light availability and photochemistry have highlighted the importance of these systems as sources of colored dissolved organic matter (CDOM). Using optical and compositional analyses, Tzortziou et al. (2008) demonstrated that brackish marshes have a strong influence on CDOM dynamics in the Rhode River subestuary of the Chesapeake Bay, exporting optically and chemically distinctive, relatively complex, high-molecular-weight (MW), aromatic-rich dissolved organic compounds throughout the year. Marsh-derived CDOM was found to have higher photoreactivity than CDOM in the adjacent estuarine waters (Tzortziou et al. 2007). In Southern California, tidally flushed salt marshes were found to be the dominant source of CDOM to coastal waters during the dry season, when there are little to no riverine inputs (Clark et al. 2008). Based on comparisons between CDOM optical properties measured in the marsh ebb waters vs. marsh-plant leachates, the study concluded that marsh soil is most likely the major source of exported CDOM in that system, with a minor contribution from fresh plant materials.

Relative to information on the amount and direction of tidal exchanges at the marsh-estuary interface, much less is known about the distribution, processing and fate of the distinctive colored dissolved organic compounds derived from marshes once they are exported into the estuary, and the spatial extent to which this marsh 'signature' is distinguishable over the regional estuarine background, affecting optical, biological and biogeochemical variability in the estuary. Addressing this objective, and studying the marsh influence on spatial distributions of inorganic and organic, as well as particulate and dissolved, carbon components were the main goals of our study. In order to resolve spatial gradients associated with marsh outwelling during ebbing tide, high-spatial-resolution measurements of water physicochemical parameters, DOC and DIC concentrations, chl $a$ and CDOM optical properties were performed along several transects extending more than $1500 \mathrm{~m}$ in the Rhode River estuary. Spatial gradients associated with individual marshes versus other terrestrial and wetland sources in this system were resolved with additional transects along a shoreline adjacent to both marsh and forest vegetation.

\section{MATERIALS AND METHODS}

Site description. Brackish and freshwater tidal marshes cover about $700 \mathrm{~km}^{2}$ along the shores of the 
Chesapeake Bay, the largest estuary in the USA and historically one of the most productive in the world (Mencken 1940, Cestti et al. 2003). The Rhode River is a turbid, eutrophic subestuary on the western shore of the Chesapeake Bay in Maryland $\left(38.88^{\circ} \mathrm{N}, 76.53^{\circ} \mathrm{W}\right.$; Fig. 1). It is $5.5 \mathrm{~km}^{2}$ in area, and its average depth is $2 \mathrm{~m}$, with a maximum of $4 \mathrm{~m}$ close to the confluence with the Chesapeake Bay. The tidal forcing affecting the subestuary is semi-diurnal. The mean tidal amplitude is $0.3 \mathrm{~m}$, but water level is also affected by weather conditions (Jordan et al. 1986). Salinity varies seasonally from 5 to 20 at the mouth of the Rhode River, depending mainly on the flow of the Susquehanna River, and from 0 to 14 at the head, depending mainly on the flow of Muddy Creek, which is the uppermost section of the Rhode River (Fig. 1) and the primary tributary and freshwater source to the subestuary (Gallegos et al. 2005).
Muddy Creek drains a $23 \mathrm{~km}^{2}$ watershed (Fig. 1), which is $63 \%$ forest, $18 \%$ cropland, $13 \%$ pasture and $7 \%$ residential (Jordan et al. 1991). Muddy Creek consists of $0.23 \mathrm{~km}^{2}$ of shallow (less than $1 \mathrm{~m}$ deep) mudflat and creeks bordered by intertidal mudflats, low marsh, and $0.22 \mathrm{~km}^{2}$ of high-elevation marshes (Jordan et al. 1986). It should be noted that most of the former low-elevation marshes dominated by Typha angustifolia have become intertidal mudflat due to muskrat foraging (T. E. Jordan pers. comm.).

The high-elevation marshes (from 0.4 to $0.6 \mathrm{~m}$ above mean low water) are covered mainly by Spartina patens, S. cynosuroides, Distichlis spicata, Iva frutescens and Schoenoplectus americanus (formerly Scirpus olneyi), and are representative of brackish high marshes of mid-Atlantic North America. The Kirkpatrick marsh, located along the south shoreline of the subestuary, is the largest high-elevation marsh in this

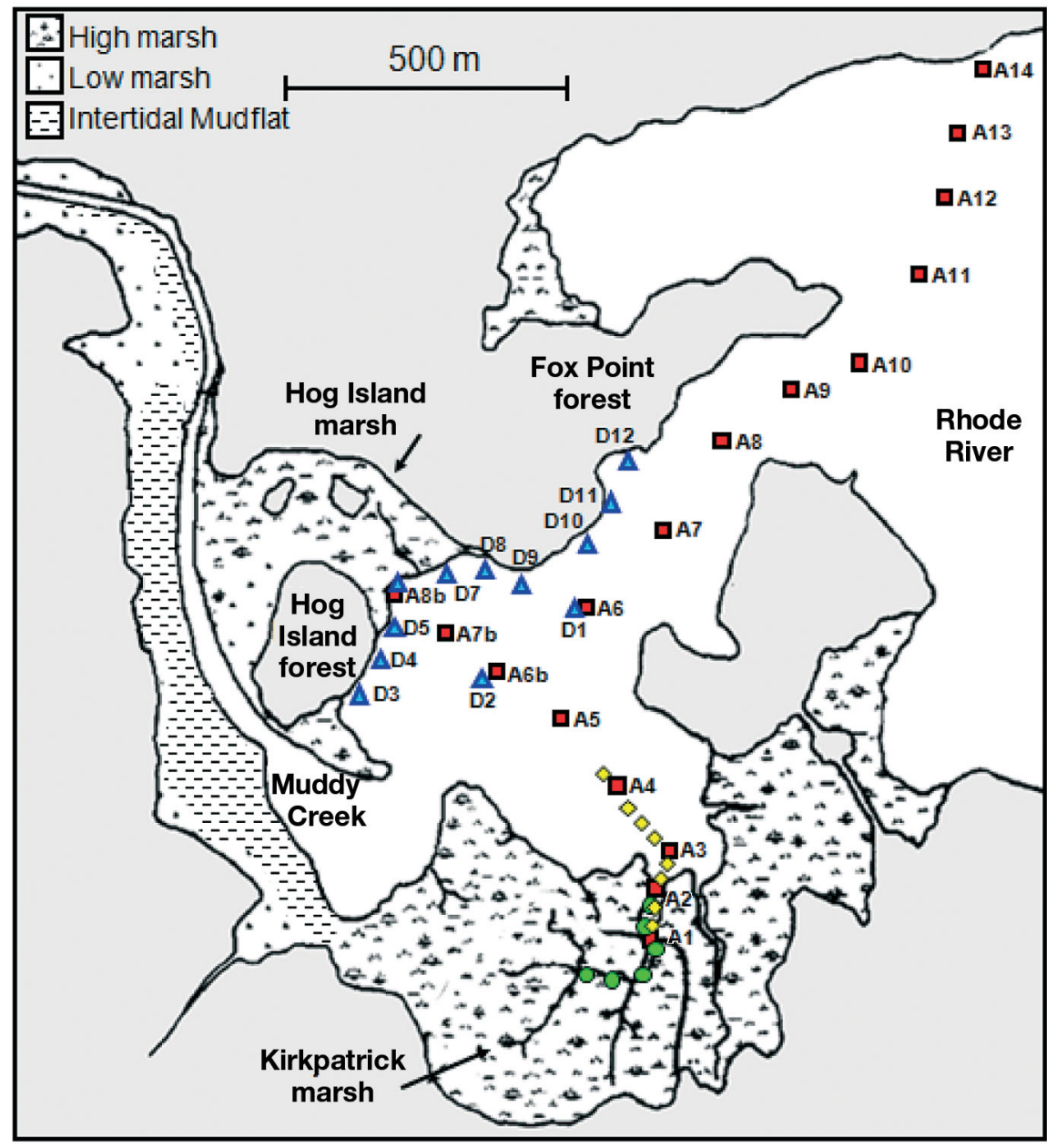

- Transect A: June 16

Transect B: July 7

- Transect C: July 17

$\triangle$ Transect D: July 30

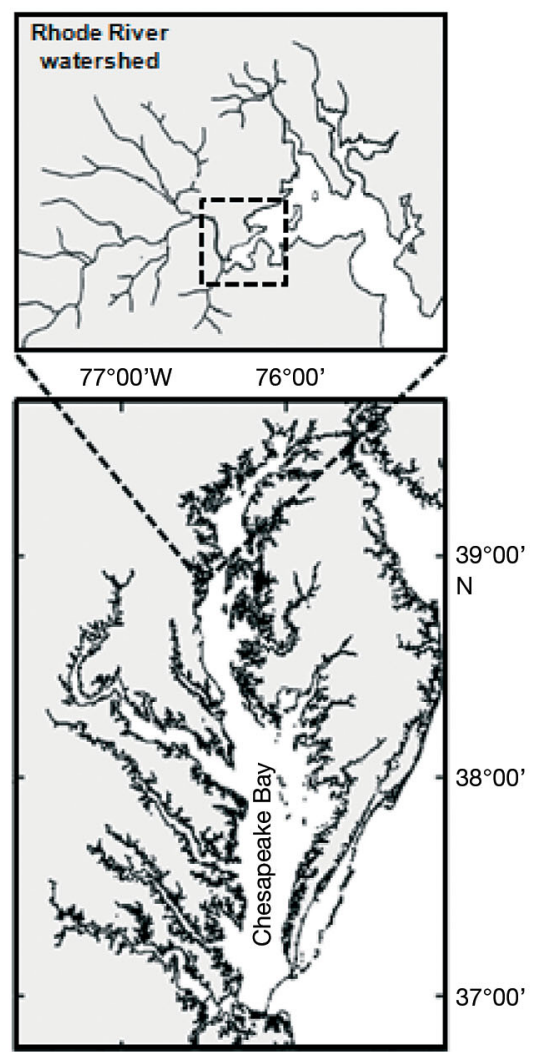

Fig. 1. Right panels: location of the Rhode River subestuary along the western shore of the Chesapeake Bay. The square on the upper-right panel shows the study area in the Rhode River watershed. Left panel: the upper-to-middle segment of the Rhode River subestuary, its watershed, and the intertidal and subtidal zones covered by low marshes, high marshes and mudflats. Sampling site locations are shown along 4 transects (A, B, C, D) 
system. A smaller high-elevation marsh is Hog Island, extending along the north shoreline of the subestuary (Fig. 1). The soils at the site are organic (>80\% organic matter) to a depth of $\sim 5 \mathrm{~m}$.

Sample collection and in situ measurements. To examine the influence of the Kirkpatrick marsh on estuarine dissolved organic matter (DOM), algal biomass, DIC concentrations and $\mathrm{CO}_{2}$ dynamics, samples were collected along 4 transects in the upper segment of the Rhode River (Fig. 1). Sampling was performed during the summer of 2008 (June 16 to July 30), when plant biomass in the marsh was peaking. Weather conditions were drier than the long-term average for June and July (>20 yr record; US Naval Academy weather station, Annapolis, Maryland), and no large rain events were observed during our sampling period. Variability in precipitation among different sampling days was small, with weekly total rainfall between 0 and $15 \mathrm{~mm}$ $\mathrm{wk}^{-1}$ for the $1 \mathrm{wk}$ previous to each transect. The highest daily total rainfall during any of these $1 \mathrm{wk}$ periods was $10 \mathrm{~mm} \mathrm{~d}^{-1}$. To capture the spatial distribution of the material flowing out of the marshes to the estuary, all samples were collected at ebbing (near to low) tide.

Sampling along the first transect (Transect A, shown as squares in Fig. 1) was performed on June 16. Spatial resolution of the sampling was $\sim 50 \mathrm{~m}$ close to the marsh, increasing to 100 and $150 \mathrm{~m}$ further away from the marsh influence. The starting point was a weir located at the mouth of the main creek draining the Kirkpatrick marsh (Site A1, at $38.8755^{\circ} \mathrm{N}, 76.5463^{\circ} \mathrm{W}$ ). This creek flows through the marsh into the Muddy Creek mudflat area (Fig. 1). At Site A5 (located at a distance of $360 \mathrm{~m}$ from site A1, and at the center of Muddy Creek's subtidal mudflat), Transect A was divided into 2 legs. The first leg (sampling sites A6 to A14) extended to the Rhode River estuarine basin. Sampling site A14 was located in the mid part of the Rhode River subestuary at a distance of $1.6 \mathrm{~km}$ from the Kirkpatrick marsh, and was selected as the estuarine end-member of Transect A, representing estuarine background conditions in this system. Note that the chemical characteristics of the estuarine end-member reflect the influence of wetland, upland and groundwater inputs under relatively well-mixed conditions. The second leg of Transect A (sampling sites A6b to A8b) was extended to the Hog Island high-elevation marshes, cutting across Muddy Creek.

Based on the results of these measurements, sampling along Transect B was performed on July 7 as a higherspatial-resolution sampling of the segment of Transect A that showed the largest gradient in all measured quantities (sampling sites A1 to A4). Spatial resolution of Transect B (10 sampling sites total) was, on average, $25 \mathrm{~m}$. (Transect B is shown as diamonds in Fig. 1).
To examine more closely the dynamics of DOM within the marsh before material is tidally flushed into the river, 6 additional samples were collected (on July 17) at high spatial resolution along the creek draining the Kirkpatrick marsh (Transect C). This transect extended from sampling site $\mathrm{C} 1$ at $112 \mathrm{~m}$ upstream of the marsh weir, to site C6 at $60 \mathrm{~m}$ downstream of the weir. The total length of the transect was $172 \mathrm{~m}$, and spatial resolution was, on average, $25 \mathrm{~m}$. (Sampling sites along Transect $\mathrm{C}$ are shown as circles in Fig. 1).

The north shoreline of Muddy Creek is covered by marshes (Hog Island marsh), forests (Fox Point forest) and forests surrounded by marshes (the Hog Island forest; see Fig. 1). Sampling along Transect D (triangles in Fig. 1) was performed on July 30 along the north shoreline of Muddy Creek, to compare the properties and composition of estuarine CDOM adjacent to marshes versus upland forest vegetation.

Water samples for optical and compositional analysis of DOM were collected in 0.51 Nalgene bottles and filtered within $3 \mathrm{~h}$ of collection through $0.22 \mu \mathrm{m}$ (pore-diameter) filters. (Samples for DIC analysis were handled differently, as described below.) Filtered water was stored in the dark at $4^{\circ} \mathrm{C}$ for $<1 \mathrm{wk}$. Samples were warmed to room temperature before optical analysis.

Measurements of salinity and $\mathrm{pH}$ were performed on the whole water samples immediately upon collection, using a YSI 556 multiprobe system.

Chl a concentrations. Chl a concentrations were measured fluorometrically using EPA Method 445.0, with minor modifications (Arar \& Collins 1997). Sample water $(100 \mathrm{ml})$ was $\mathrm{GF} / \mathrm{F}$ filtered $(47 \mathrm{~mm})$. The filters were then folded and placed into $20 \mathrm{ml}$ scintillation vials. Refrigerated samples were extracted (without grinding) in $10 \mathrm{ml} \mathrm{90 \%} \mathrm{acetone/water} \mathrm{(v/v)} \mathrm{overnight.}$ Fluorescence of the extract was measured on a Turner Designs 10AU fluorometer. The extract was then acidified with 2 drops $1 \mathrm{~N} \mathrm{HCl}$ and remeasured. Chl $a$ and phaeo a were calculated from acidified and non-acidified fluorescence values. The absence of chl $b$-containing organisms, which can interfere with chl $a$ and phaeo a estimates using Method 445.0, was verified by microscopic examination of the samples (S. Hedrick pers. comm.). The fluorometer was calibrated with chl a from spinach (Sigma Chemical).

DOC concentrations. Samples for DOC analysis were filtered through $0.22 \mu \mathrm{m}$ polycarbonate filters into cleaned (10\% HCl/water, v/v) and pre-combusted amber glass bottles. DOC concentrations were determined by high-temperature combustion using a Shimadzu TOC-V CSH Total Organic Carbon Analyzer. Total carbon standard calibration curves were measured according to protocol. Multiple deionized (DI) water blanks were run until background counts were 
low and steady before proceeding with sample analysis.

Total DIC, $\mathrm{CO}_{2}$ and $\mathrm{HCO}_{3}{ }^{-}$measurements. Samples for DIC analysis were filtered at the time of collection (in the field) through a $0.22 \mu \mathrm{m}$ filter using a syringe, and were collected into precleaned, acid-washed glass serum vials. The vials were completely filled to exclude air bubbles, sealed with a septum and stored on ice or refrigerated until analysis, which occurred within $24 \mathrm{~h}$ of collection. DIC concentrations were determined on the Shimadzu TOC-V CSH Carbon Analyzer after acidification and sparging. $\mathrm{CO}_{2}$ and $\mathrm{HCO}_{3}{ }^{-}$values were calculated from total DIC concentrations, $\mathrm{pH}$, salinity and temperature measurements using the macros in the Microsoft Excel spreadsheet co2sys.xls (Lewis \& Wallace 1998, Pelletier et al. 2007) with dissociation constants for estuarine waters from Cai \& Wang (1998) and default values for other parameters.

CDOM absorption analysis. Measurements of CDOM absorption were performed using a CARY-IV dual-beam spectrophotometer. Due to the high optical thickness of the samples, absorbance measurements were performed using $1 \mathrm{~cm}$ pathlength, acid-cleaned and DI-water-rinsed quartz cuvettes. Measurements were baseline-corrected using DI water. Instrument drift was monitored by measuring a DI-water blank before each sample. Duplicate measurements were performed for each sample. Measurements covered the spectral range from 270 to $750 \mathrm{~nm}$ (1 nm bandwidth and interval). CDOM absorption coefficients $a_{\mathrm{CDOM}}(\lambda)$ were estimated from measured optical densities (OD) after multiplying by 2.303 and dividing by the pathlength $\mathrm{l}_{\mathrm{g}}$ (0.01 $\mathrm{m}$ for a $1 \mathrm{~cm}$ cuvette) (Kirk 1994):

$$
a_{\mathrm{CDOM}}(\lambda)=2.303 \frac{\mathrm{OD}}{\mathrm{l}_{\mathrm{g}}}=2.303 \frac{\mathrm{OD}}{0.01}\left(\mathrm{~m}^{-1}\right)
$$

Since absorption by CDOM decreases exponentially with increasing wavelength, the exponential slope, $\mathrm{S}_{\mathrm{CDOM}}$, was estimated after applying non-linear exponential regression to $a_{\mathrm{CDOM}}(\lambda)$ measured in the complete spectral range of the measurements from 270 to $750 \mathrm{~nm}$ (Tzortziou et al. 2007). $\mathrm{R}^{2}$ values of the nonlinear exponential fits were in all cases $>0.99$. The average range between duplicate determinations of $\mathrm{S}_{\mathrm{CDOM}}$ was $0.0001 \mathrm{~nm}^{-1}$. In addition, we estimated the spectral slopes in the interval from 275 to $295 \mathrm{~nm}$ $\left(\mathrm{S}_{275-295}\right)$ and from 350 to $400 \mathrm{~nm}\left(\mathrm{~S}_{350-400}\right)$, and then estimated the slope ratio $S_{R}$ as the ratio of $S_{275-295}$ to $\mathrm{S}_{350-400}$ following Helms et al. (2008). $\mathrm{S}_{275-295}$ and $\mathrm{S}_{350-400}$ were calculated using linear regression of the log-transformed absorption spectra. Helms et al. (2008) estimated the $\mathrm{S}_{275-295}$ and $\mathrm{S}_{350-400}$ slopes using both the log-transformed linear regression and the non-linear regression methods and reported differences $<1 \%$.

Whereas variability in CDOM absorption reflects changes in both CDOM amount and chemical structure, variability in the mass-specific CDOM absorption is related only to CDOM composition. Although not all DOC is colored, CDOM absorption at $440 \mathrm{~nm}$ was normalized to DOC concentration, $a^{*}{ }_{\mathrm{CDOM}}(\lambda)=a_{\mathrm{CDOM}}(440)$ $\div$ DOC, as a measure of CDOM absorption per unit DOC concentration.

CDOM fluorescence analysis. Measurements of CDOM fluorescence were made on a SPEX Fluoromax-3 spectrofluorometer (Jobin Yvon Horiba). The fluorescence emission measured by the signal detector $\mathrm{S}_{\mathrm{C}}$ was referenced to the signal measured by the reference detector $R_{C}$ in order to monitor and correct for fluctuations in the lamp output, in accordance with the manufacturer's protocol. Emission and excitation correction-factor files were applied in accordance with manufacturer instructions to correct for the wavelength dependencies of the optical components of each monochromator and the detectors themselves. Because of the typically high absorption of CDOM in this environment (Tzortziou et al. 2007, 2008), fluorescence spectra were corrected for absorption within the sample (inner-filter effect) in accordance with McKnight et al. (2001) and using the CDOM absorption spectra measured spectrophotometrically. Bandwidths were set to $5 \mathrm{~nm}$ for both excitation and emission. A spectrum of DI water was subtracted as a blank to correct for Raman scattering effects.

The synchronous fluorescence (SF) technique was used to investigate variability in composition and optical properties of CDOM in this marsh-estuarine system. An SF spectrum is a subset of the excitationemission matrix in which excitation and emission are at a constant wavelength offset $\left(\delta \lambda=\lambda_{\text {em }}-\lambda_{\text {exc }}\right.$ ) (Lloyd 1971, Ferrari \& Mingazzini 1995). A wavelength offset of $\delta \lambda=14 \mathrm{~nm}$ was used in our SF measurements $\left(\lambda_{\mathrm{em}}\right.$ in the range of 300 to $620 \mathrm{~nm}, 1 \mathrm{~nm}$ resolution), based on previous results showing that this wavelength offset is optimal for resolving differences in CDOM between sources (Belzile et al. 2002). This wavelength offset is also a good compromise between more structural features and lower signal-to-noise ratios in the SF spectra. The average difference between duplicate measurements of SF was $1.6 \%$.

\section{RESULTS}

\section{Salinity and pH}

Our sampling along transects in the Rhode River covered a period of 45 d, from June 14 to July 30, 2008. 
Due to relatively dry summer conditions, there was a general increase in salinity over the period (Fig. 2A). Salinity at the Kirkpatrick marsh weir (located at the tidal marsh creek end-member and measured during sampling along all 3 transects A, B and C) increased from 5.8 on June 16 (Transect A) to 8.4 on July 17 (Transect C). Spatial variability along each transect was considerably smaller than temporal variability, with salinity varying by $1.7,0.2,0.3$ and 0.9 along Transects A, B, C and D, respectively. Salinity increased with increasing distance from the marsh (Fig. 2A).

$\mathrm{pH}$ ranged from 6.7 to 7.8 . The lowest values were measured consistently within the marsh and at the tidal marsh creek end-member, increasing with distance downstream within the subestuary (Fig. 2B). Unlike salinity, $\mathrm{pH}$ showed no large temporal variability during our sampling period, with high consistency in $\mathrm{pH}$ values among the 4 transects. Measured values at the Kirkpatrick marsh weir were 6.8, 6.8 and 6.9 during sampling along Transects A, B and C, respectively.

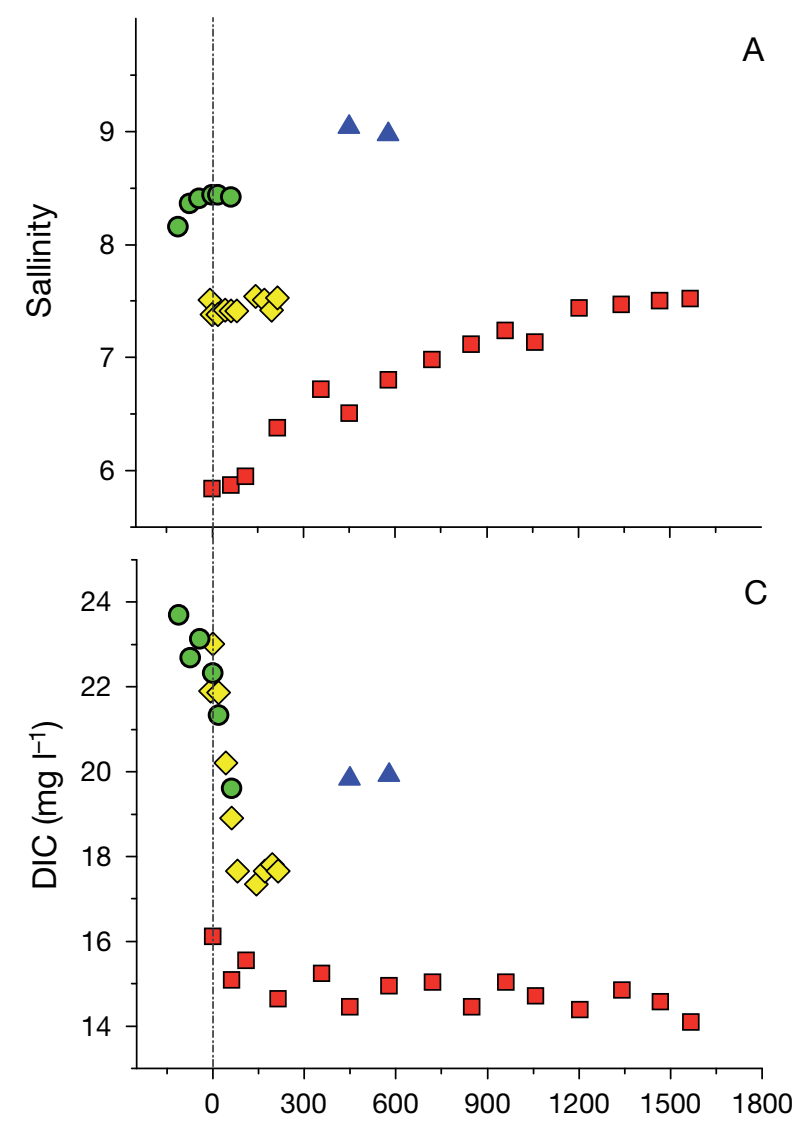

The spatial gradients we measured in optical and biogeochemical variables along the transects extending from the Kirkpatrick marsh to the Rhode River subestuary are presented below and are shown in Figs. 2, 3 \& 4 . Results from 2 additional transects, one extending from the Kirkpatrick to the Hog Island marsh (second leg on Transect A) and the other along the watershed shoreline of Muddy Creek (Transect D), are presented in Figs. 5 \& 6, respectively.

\section{DIC content and $p \mathrm{CO}_{2}$}

Measurements along Transect A revealed large spatial variability in both DIC content and partial pressure of carbon dioxide $\left(p \mathrm{CO}_{2}\right)$ levels, with the strongest gradient observed within $215 \mathrm{~m}$ of the marsh weir (sampling sites A1 to A4). For this reason, this segment of Transect A was sampled at higher spatial resolution during our sampling along Transects $B$ and $C$ (Fig. 2C,D).

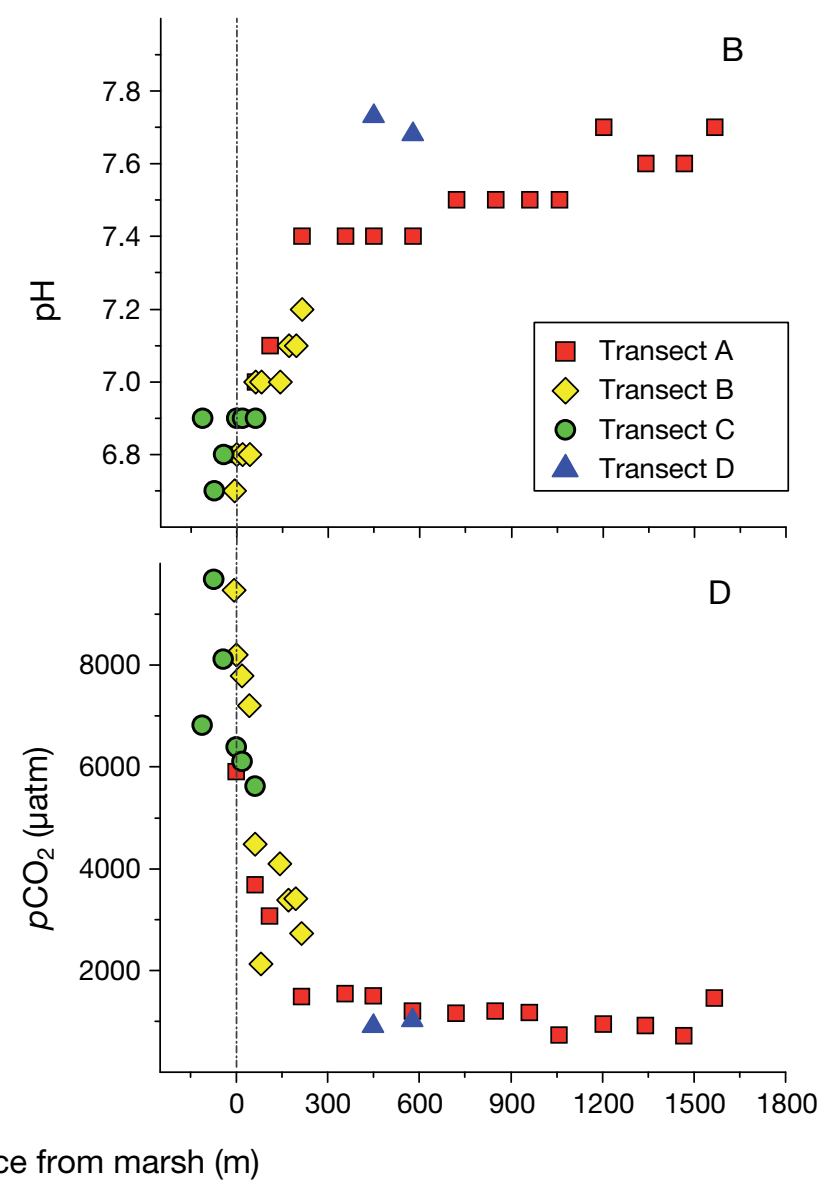

Fig. 2. Change in (A) salinity, (B) $\mathrm{pH},(\mathrm{C})$ dissolved inorganic carbon (DIC) and (D) partial pressure of carbon dioxide ( $\left.p \mathrm{CO}_{2}\right)$, vs. distance from the Kirkpatrick marsh. Measurements from each transect performed from the marsh to the estuary (Transects A, B, C, D) are shown using different symbols as indicated in panel B. Only 2 sites from Transect D are shown here (D1 and D2, see Fig. 1) because the rest of the sites from Transect D were along the north Muddy Creek shoreline 


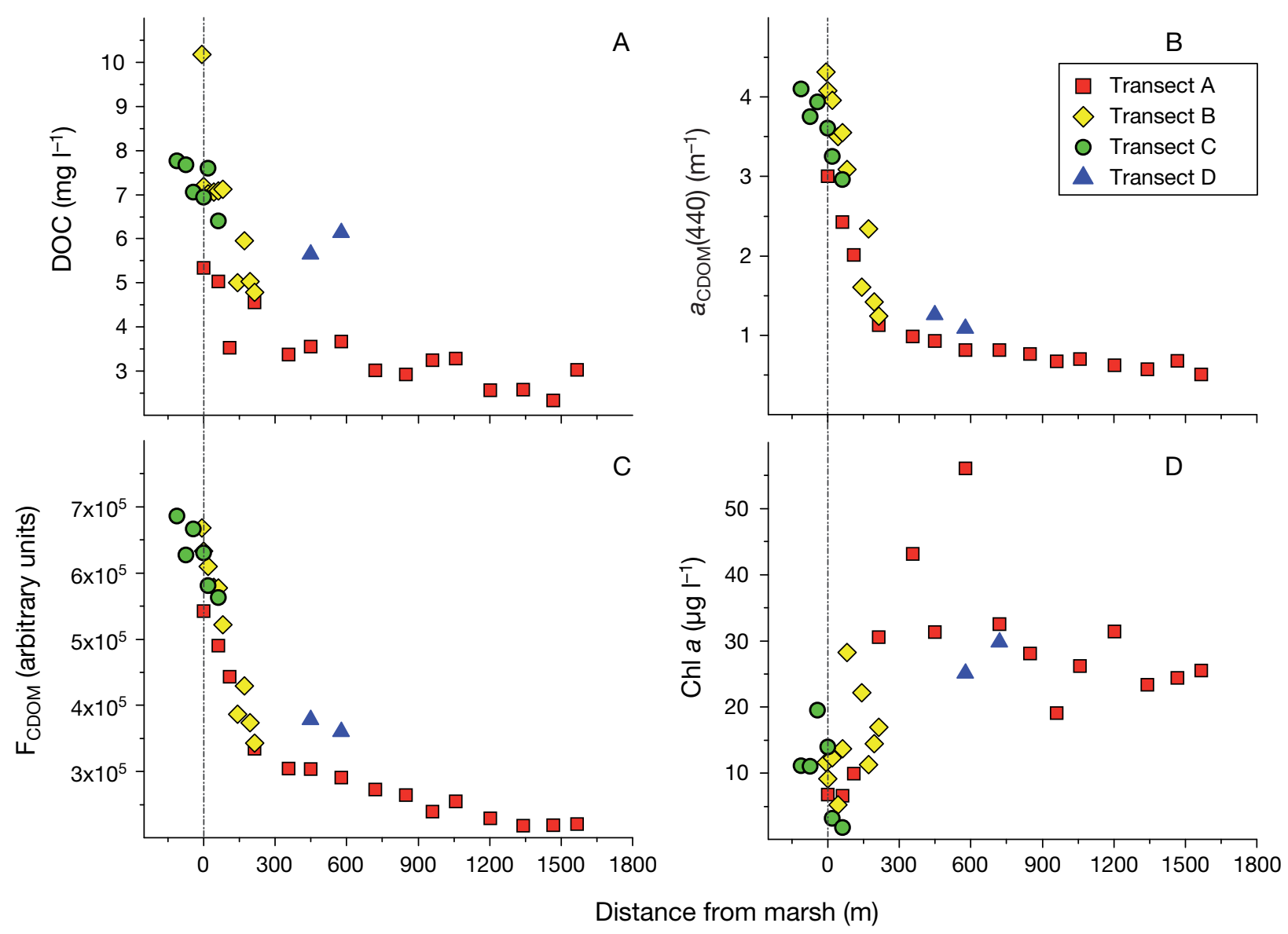

Fig. 3. Change in (A) dissolved organic carbon (DOC), (B) colored dissolved organic matter (CDOM) absorption coefficient at $440 \mathrm{~nm}$ [ $\left.a_{\mathrm{CDOM}}\right](440),(\mathrm{C}) \mathrm{CDOM}$ fluorescence $\left(\mathrm{F}_{\mathrm{CDOM}}\right.$ i excitation: $350 \mathrm{~nm}$, emission: $\left.364 \mathrm{~nm}\right)$ and (D) chl $a$, vs. distance from the Kirkpatrick marsh. The location and number of sites is the same as in Fig. 2

Maximum values of DIC concentration were consistently observed within the Kirkpatrick marsh, reaching $24 \mathrm{mg} \mathrm{l}^{-1}$ at Site C1, which was located the furthest upstream in the tidal marsh creek (Fig. 2C). This was about twice as high as the DIC concentration of $14 \mathrm{mg}$ $\mathrm{I}^{-1}$ measured at the Rhode River estuarine end-member (Fig. 1D). Most of the decrease in DIC was observed within a distance of $<300 \mathrm{~m}$ from the marsh.

Dissolved $\mathrm{CO}_{2}\left(\mathrm{CO}_{2}\right)$ at the surface of Rhode River

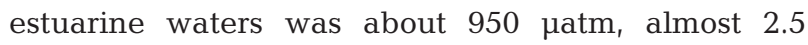
times greater than atmospheric equilibrium (Fig. 2D). Within the Kirkpatrick marsh, $p \mathrm{CO}_{2}$ was 10 times higher than its estuarine value, reaching a maximum of $>9690 \mu \mathrm{atm}$. Measured $p \mathrm{CO}_{2}$ at the Kirkpatrick marsh weir varied from 5900 to 8200 patm ( 40\% difference) among different transects, suggesting relatively low temporal variability in $p \mathrm{CO}_{2}$ levels. As in the case of DIC, the strongest gradient in $p \mathrm{CO}_{2}$ was observed within a distance of $<300 \mathrm{~m}$ from the marsh weir.

\section{DOC concentrations}

DOC concentrations showed large spatial variability, decreasing with distance from the marsh (Fig. 3A). DOC within the Kirkpatrick marsh reached a maximum concentration of $10 \mathrm{mg} \mathrm{l}^{-1}$, more than 3.5 times higher than its estuarine value of $2.8 \mathrm{mg} \mathrm{l}^{-1}$. At the marsh weir, DOC varied from 5.3 to $7.2 \mathrm{mg} \mathrm{l}^{-1}$ among different transects, with an average of $6.5 \mathrm{mg} \mathrm{l}^{-1}$. A decrease by almost a factor of 2 from 6.5 to $3.4 \mathrm{mg} \mathrm{l}^{-1}$ was observed within a distance of $350 \mathrm{~m}$ from the marshland, as marsh-derived material was exported to the Muddy Creek subtidal mudflat and mixed with estuarine water.

\section{CDOM optical properties}

Consistent with changes in DOC concentration, CDOM absorption magnitude showed large spatial gradients along transects from the marsh to the Rhode 


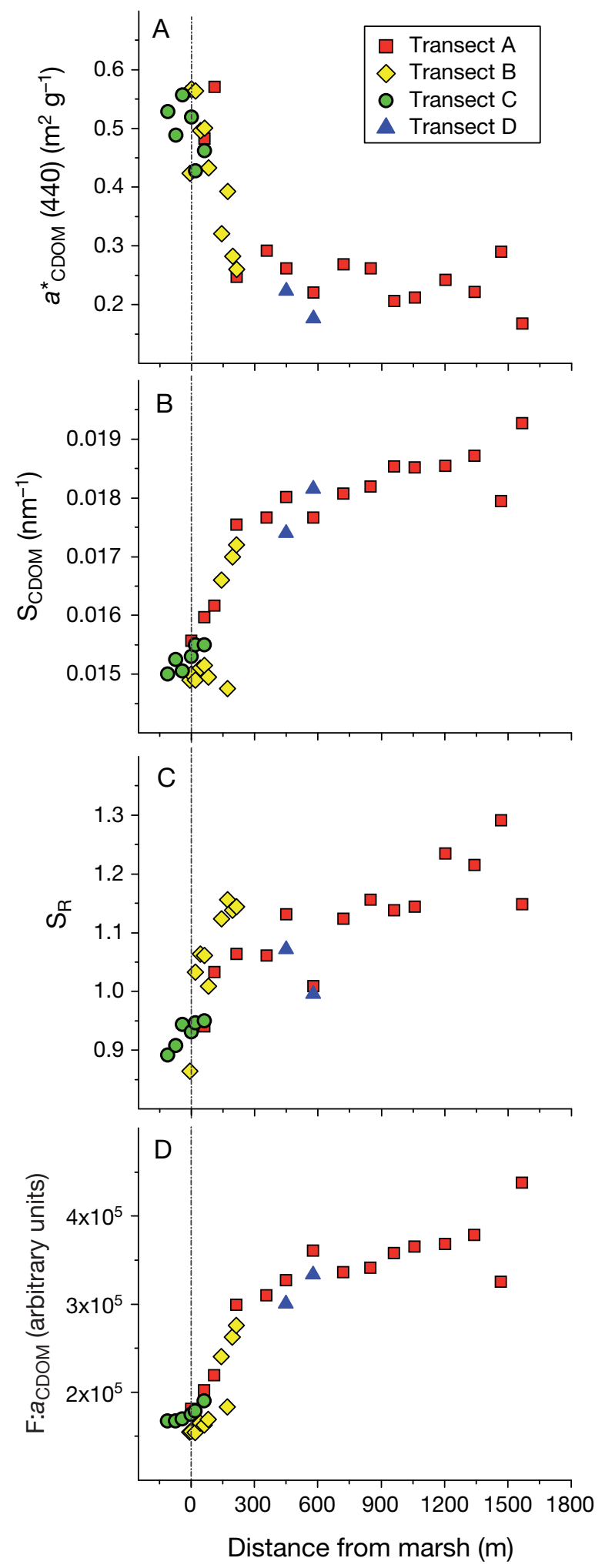

Fig. 4. Change in (A) DOC-specific CDOM absorption at $440 \mathrm{~nm}, a^{*}{ }_{\text {CDOM}}(440),(B)$ CDOM absorption spectral slope, $\mathrm{S}_{\mathrm{CDOM},}(\mathrm{C})$ slope ratio $\mathrm{S}_{\mathrm{R}}$, and (D) fluorescence per unit absorption, $\mathrm{F}: a_{\mathrm{CDOM}}$, with distance from the Kirkpatrick marsh. The location and number of sites is the same as in Figs. 2 \& 3
River estuary. (Absorption is shown at $440 \mathrm{~nm}$ in Fig. 3B, because this is often chosen as the reference wavelength for CDOM absorption, e.g. Carder et al. 1989, Gallegos et al. 2005; qualitatively similar results were observed at other wavelengths.) CDOM absorption values were consistent among different transects, despite temporal variability in water physicochemical properties (e.g. salinity, $\mathrm{pH}$, temperature). $a_{\mathrm{CDOM}}(440)$ showed a maximum value of $4.3 \mathrm{~m}^{-1}$ within the marsh, decreasing to $3.6 \mathrm{~m}^{-1}$ at the marsh weir (marshestuary interface). CDOM absorption decreased by a factor of more than 3 to $0.98 \mathrm{~m}^{-1}$ within $350 \mathrm{~m}$ of the marsh. Background levels of $a_{\mathrm{CDOM}}(440)$ in the estuary were $\sim 0.5 \mathrm{~m}^{-1}$. CDOM fluorescence followed a similar pattern to CDOM absorption. Fluorescence $(\mathrm{Exc} / \mathrm{Em}=$ 350/364) at the marsh weir was twice as much as that in the center of the Muddy Creek subtidal mudflat (350 $\mathrm{m}$ distance from A1) and 2.6 times higher than that in the Rhode River estuary (Fig. 3C). Like absorption values, measured CDOM fluorescence values were consistent among different transects despite changes in environmental parameters during the $45 \mathrm{~d}$ sampling period.

The variability in CDOM absorption and fluorescence magnitude was partly due to variability in DOC concentration. We found strong dependence of the optical parameters on DOC concentration, with correlation coefficients $\mathrm{R}=0.91$ between DOC and CDOM absorption, and $\mathrm{R}=0.92$ between DOC and CDOM fluorescence $(n=33)$.

Despite the strong correlation between $a_{\mathrm{CDOM}}$ and DOC, the DOC-specific CDOM absorption, $a^{*}{ }_{\text {CDOM }}$, also decreased from the marsh to the estuary (Fig. 4A), reflecting changes in the quality and composition of CDOM. $a^{*}{ }_{\mathrm{CDOM}}(440)$ in the tidal marsh creek was $\sim 0.55 \mathrm{~m}^{2} \mathrm{~g}^{-1}$, decreasing by a factor of 2 to $0.25 \mathrm{~m}^{2} \mathrm{~g}^{-1}$ in waters over the Muddy Creek subtidal mudflat (Site A4 at a distance of $215 \mathrm{~m}$ from the marsh weir). $a^{*}{ }_{\mathrm{CDOM}}(440)$ in the Rhode River estuary (Sites A11 to A15) was on average $0.23 \mathrm{~m}^{2} \mathrm{~g}^{-1}$ (SD = 0.04). Water close to the marsh was also characterized by a considerably lower CDOM absorption spectral slope (Fig. 4B). $\mathrm{S}_{\mathrm{CDOM}}$ at the Kirkpatrick marsh weir was on average $0.0153 \mathrm{~nm}^{-1}$ with low variability among transects $(\mathrm{SD}=0.0003)$. Similar values were measured within the marsh, with $\mathrm{S}_{\mathrm{CDOM}}$ reaching a minimum of $0.0150 \mathrm{~nm}^{-1}$ at the site furthest upstream within the Kirkpatrick marsh creek. $\mathrm{S}_{\mathrm{CDOM}}$ increased with increasing distance from the marsh to $0.0174 \mathrm{~nm}^{-1}$ at a distance of $215 \mathrm{~m}$ from the weir, reaching a value of 0.0186 ( $\mathrm{SD}=0.0005)$ at the Rhode River estuarine end-member. The absorption spectral slope ratio, $\mathrm{S}_{\mathrm{R}}$, showed a consistent increase along the marshestuarine gradient in all transects. $S_{R}$ ranged from a minimum of 0.86 in the marsh to a maximum value 


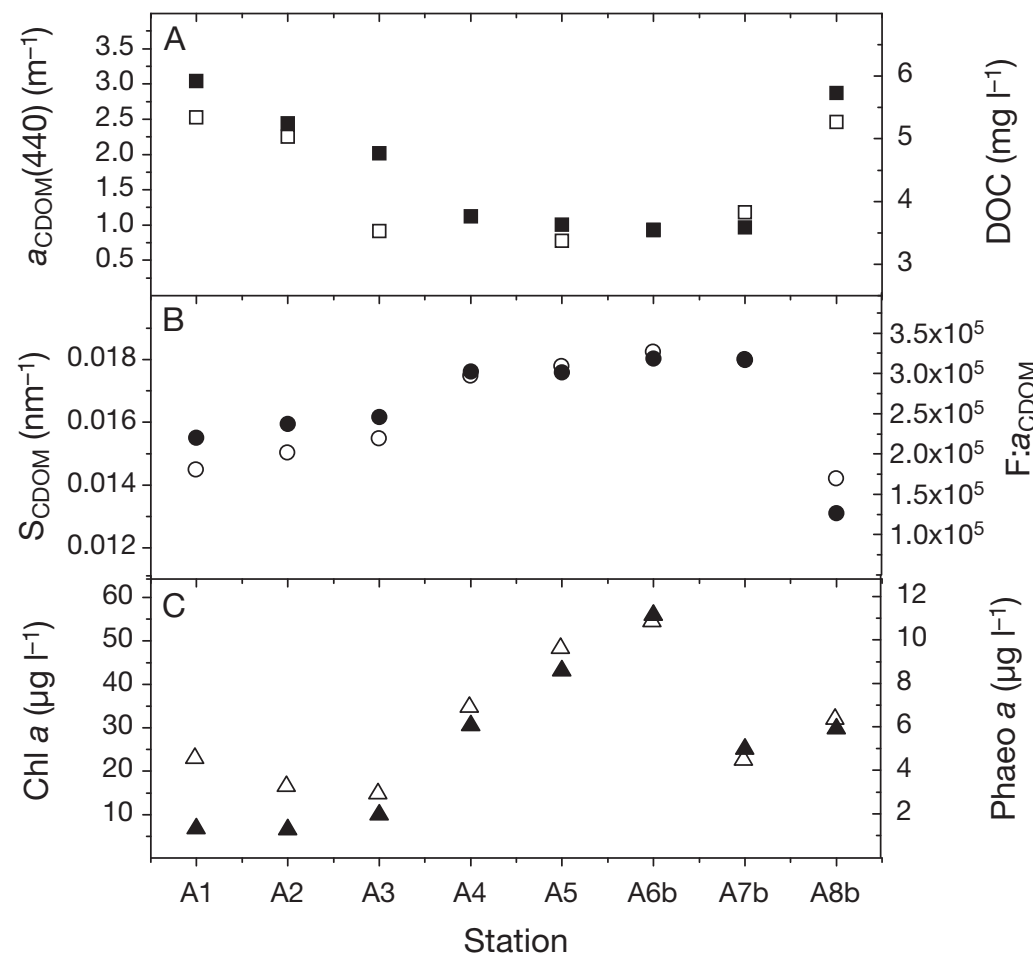

Fig. 5. Change in (A) $a_{\mathrm{CDOM}}(440)$ (solid squares) and DOC concentration (open squares), (B) $\mathrm{S}_{\mathrm{CDOM}}$ (solid circles) and F: $a_{\mathrm{CDOM}}$ (open circles), (C) chl a (solid triangles) and phaeo a (open triangles) concentrations, along Transect A (Sites A1 to A5) and its second leg (Sites A6b to A8b) that was extended from the Kirkpatrick marsh (A1) to the Hog Island marsh (A8b) across the Muddy Creek's shallow mudflat (see Fig. 1)

of 1.29 at the Rhode River estuarine end-member (Fig. 4C).

A similar pattern to $\mathrm{S}_{\mathrm{CDOM}}$ was observed in the ratio of CDOM fluorescence to absorption ( $\left.F: a_{C D O M}\right)$, used here as a measure of the fluorescence yield. A strong correlation was found between $\mathrm{S}_{\mathrm{CDOM}}$ and $\mathrm{F}: \mathrm{a}_{\mathrm{CDOM}}(\mathrm{R}=$ $0.99, \mathrm{n}=33$ ). $\mathrm{F}: \mathrm{a}_{\mathrm{CDOM}}$ close to the marsh was relatively low, increasing by more than a factor of 2 in the Rhode River estuary (Fig. 4D). As in the case of $\mathrm{S}_{\mathrm{CDOM}}$, temporal variability in $\mathrm{F}: \mathrm{a}_{\mathrm{CDOM}}$ among transects was relatively small.

\section{Chl a concentrations}

Chl a distribution followed a different pattern from DOC distribution (Fig. 3D). Concentrations along the tidal creek draining the Kirkpatrick marsh had an average value of $9.7 \mu^{-1}(\mathrm{SD}=6.6)$. These were significantly lower than the chl a values of $25.5 \mu \mathrm{g} \mathrm{l^{-1 }}$ measured at the Rhode River estuarine end-member (Site A14). Maximum chl a amounts were observed in the Muddy Creek mudflat area, with concentrations reaching 43 and $56 \mu \mathrm{g} \mathrm{l}^{-1}$ at Sites A5 and A6b, respectively.

\section{Marsh to marsh transect}

To examine the spatial variability in water properties along a transect connecting 2 different marsh systems in the Rhode River, the second leg of Transect A was extended from the Kirkpatrick marsh to the Hog Island marsh across Muddy Creek's subtidal mudflat (Fig. 1). The Hog Island marsh is a brackish high-elevation marsh with similar vegetation characteristics to the Kirkpatrick marsh. DOC concentration along this segment of Transect A decreased from $5.34 \mathrm{mg} \mathrm{l}^{-1}$ at the Kirkpatrick marsh shoreline to a minimum of $3.37 \mathrm{mg} \mathrm{l}^{-1}$ at the center of the Muddy Creek mudflat (Site A5), increasing to $5.27 \mathrm{mg} \mathrm{l}^{-1}$ at the Hog Island marsh shoreline (Fig. 5A). $a_{\mathrm{CDOM}}(440)$ decreased from a maximum value of $3 \mathrm{~m}^{-1}$ at the Kirkpatrick marsh weir, to a minimum value of $0.98 \mathrm{~m}^{-1}$ at the centre of the Muddy Creek mudflat, and then increased to $2.97 \mathrm{~m}^{-1}$ close to the Hog Island marsh (Fig. 5A). These changes in DOC and $a_{\mathrm{CDOM}}$ were due to changes in both quantity and quality of CDOM, since the DOC-specific CDOM absorption, $a^{*}{ }_{\mathrm{CDOM}}(440)$, changed from 0.5618 to 0.2908 to $0.5636 \mathrm{~m}^{2} \mathrm{~g}^{-1}$ at the 3 sampling sites. Consistent with changes in $a^{*}{ }_{\mathrm{CDOM}}(440), \mathrm{S}_{\mathrm{CDOM}}$ was $0.0155 \mathrm{~nm}^{-1}$ for CDOM samples collected from the Kirkpatrick marsh weir, increasing to $0.0177 \mathrm{~nm}^{-1}$ at the centre of the Muddy Creek mudflat, then decreasing to a minimum value of $0.0136 \mathrm{~nm}^{-1}$ at the Hog Island marsh (Fig. 5B). A similar pattern to $\mathrm{S}_{\mathrm{CDOM}}$ was observed in $\mathrm{F}: \mathrm{a}_{\mathrm{CDOM}}$. Chl a concentrations were less than $10 \mu \mathrm{g} \mathrm{l}^{-1}$ at the marsh weir, increasing to a maximum value of $56 \mu \mathrm{g} \mathrm{l}^{-1}$ at Site A6b in the Muddy Creek mudflat, and then decreasing to a range of 25 to $30 \mu \mathrm{g}$ $\mathrm{l}^{-1}$ close to the Hog Island marsh (Fig. 5C). Over the mudflat region, chl $a$ and phaeo $a$ were closely correlated. In contrast, over sites A1 to A3 in and near the Kirkpatrick marsh, chl a and phaeo a showed an inverse relationship (Fig. 5C).

\section{Variability along watershed shoreline}

Fig. 6 shows spatial patterns in DOC and CDOM optical properties along the north shoreline of Muddy Creek (Transect D), an area that was influenced both by marshes (Hog Island marsh) and forests (Fox Point forest). Since the Hog Island forest is surrounded by 


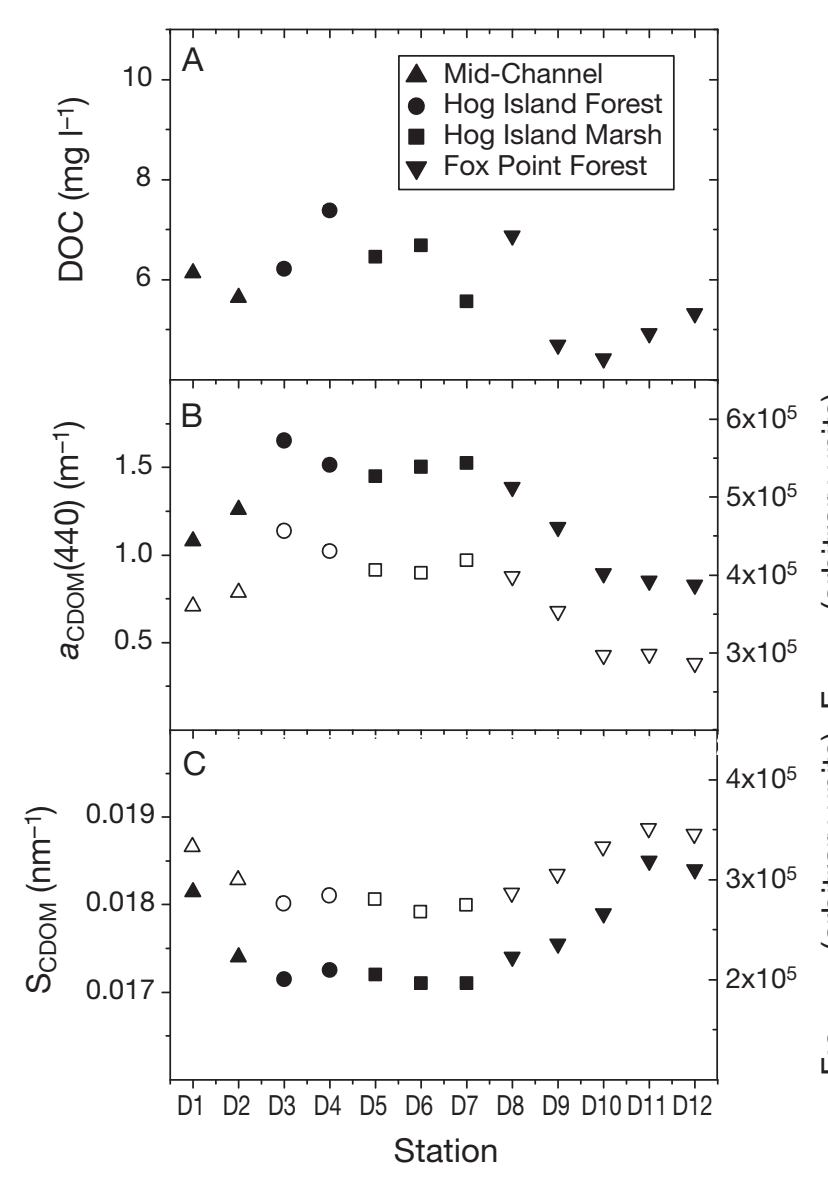

Fig. 6. Change in DOC and CDOM properties along the north shoreline of Muddy Creek, which is covered by marsh (Hog Island marsh) and forest vegetation. (A) DOC, (B) $a_{\mathrm{CDOM}}(440)$ (left axis, solid symbols) and $\mathrm{F}_{\mathrm{CDOM}}$ (right axis, open symbols), (C) $\mathrm{S}_{\mathrm{CDOM}}$ (left axis, solid symbols) and $\mathrm{F}: a_{\mathrm{CDOM}}$ (right axis, open symbols)

the Hog Island high-elevation marshes, water properties at Sites D3 and D4 are expected to be influenced by both marsh- and forest-derived material. DOC along Transect D ranged from 4.42 to $7.38 \mathrm{mg} \mathrm{l}^{-1}$, with maximum values observed along the Hog Island shoreline and minimum values at Site D10 along the Fox Island forest shoreline. CDOM absorption and fluorescence magnitude were considerably higher in the area influenced by the Hog Island marshes (Sites D3 to D7), gradually decreasing towards the Fox Point forest shoreline. CDOM absorption at $440 \mathrm{~nm}$ was $0.82 \mathrm{~m}^{-1}$ at Site D12, almost 2 times lower than the $a_{\mathrm{CDOM}}(440)$ values measured in the marsh region. $\mathrm{S}_{\mathrm{CDOM}}$ and $\mathrm{F}: a_{\mathrm{CDOM}}$ showed an opposite trend relative to CDOM absorption and fluorescence magnitude. $\mathrm{S}_{\mathrm{CDOM}}$ was considerably lower $\left(0.0171 \mathrm{~nm}^{-1}\right)$ along the Hog island marsh shoreline, increasing to $0.0185 \mathrm{~nm}^{-1}$ at Sites D11 and D12. F: $a_{\mathrm{CDOM}}$ was, again, strongly correlated with $\mathrm{S}_{\mathrm{CDOM}}(\mathrm{R}=0.98)$.

\section{Mixing processes}

The absorption magnitude and spectral slope of CDOM are shown in Fig. 7 as a function of salinity in the Rhode River estuary-watershed complex for measurements along Transect A. Changes in DOC and $F: a_{\text {CDOM }}$ with salinity followed very similar patterns to $a_{\mathrm{CDOM}}$ and $\mathrm{S}_{\mathrm{CDOM}}$, respectively (data not shown). The theoretical dilution line (from Site A1 to A14) joining the 2 end-member concentrations of marsh- versus estuarine-CDOM (solid line in Figs. 7A \& 7B) represents conservative mixing with salinity from the marsh to the estuary. The apparent non-conservative pattern could be the result of CDOM removal mechanisms due to photochemical and microbial processes. However, it could also be the result of mixing with a third source of approximately equal salinity but qualitatively different CDOM in the system, from upstream Muddy Creek (Fig. 1). In the center of the Muddy Creek mudflat (our Sites A5 and A6b) we observed a mixture of terrestrial CDOM (i.e. water from the upper reaches of Muddy Creek and forest-derived material) and marsh CDOM (i.e. exported from the Kirkpatrick and Hog Island marshes). If we consider this mixture as being derived from a combined terrestrial/marsh end-member for the second half of Transect A (from Sites A5 and A6b to A14), we can then derive a second theoretical dilution line representing conservative mixing between terrestrial/marsh and estuarine end-members from the mudflat to the estuary (dashed line in Fig. 7A,B). We found that the measured CDOM absorption properties were in good agreement with the mixing curves representing conservative behavior for this section of the transect. The characteristics of this terrestrial/marsh source are suggested by extrapolation of the conservative mixing line to the same minimum salinity observed in the marsh transect (dotted line in Fig. 7). Conservative mixing for these CDOM properties was also observed along the shoreline portion of Transect $D$ (Fig. 7C,D). The low salinity end-member in these transects was similar to the extrapolated values in Fig. 7A,B.

\section{DISCUSSION}

Long recognized as among the most productive ecosystems in the world, tidal marshes have been previously shown to affect fluxes of carbon and nutrients in adjacent estuaries and the atmosphere (Teal 1962, Valiela et al. 1973, Cai et al. 1999, 2000, Childers et al. 2000, Megonigal \& Neubauer 2009). However, uncertainties regarding the direction of some of these fluxes, the composition and degradability of materials exported, and the possible contributions, or interferences, of adjacent 


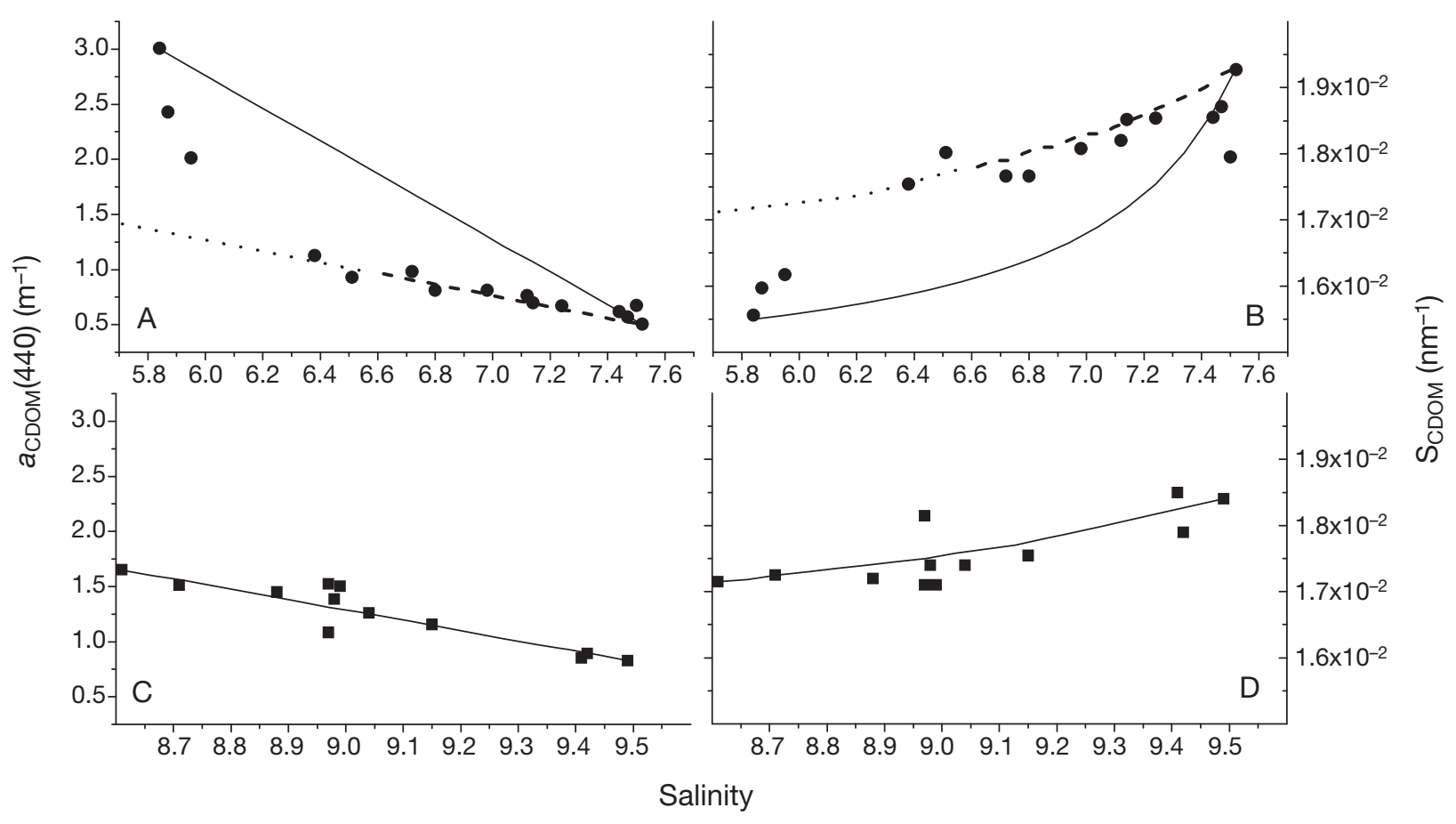

Fig. 7. Absorption properties of CDOM vs. salinity in the Rhode River estuary/tidal marsh complex. Transect $\mathrm{A}$ : (A) $a_{\mathrm{CDOM}}(440)$ and (B) $\mathrm{S}_{\mathrm{CDOM}}$ (solid circles). The theoretical dilution line joining the 2 end-member concentrations of marsh vs. estuarine CDOM (full extent of Transect A) is shown as a solid line. A second theoretical dilution line joining the 2 end-member concentrations of terrestrial (mixture of marsh and Muddy Creek water) vs. estuarine CDOM represents conservative mixing with salinity from the Muddy Creek mudflat to the estuary (dashed line). Extrapolation to minimum salinity observed (dotted line) indicates the characteristics of this terrestrial/marsh source. Changes in DOC and F: $a_{\mathrm{CDOM}}$ with salinity follow very similar patterns to $a_{\mathrm{CDOM}}$ and $\mathrm{S}_{\mathrm{CDOM}}$, respectively (data not shown here). Transect D: (C) $a_{\mathrm{CDOM}}(440)$ (D) $\mathrm{S}_{\mathrm{CDOM}}$. The theoretical line representing conservative mixing with salinity is shown as a solid line

ecosystems (e.g. mudflats) to marsh nutrient release often result in uncertainties regarding the influence of marsh tidal exchanges on biogeochemical gradients in the estuary. Our high-spatial-resolution transects in the Rhode River estuary-marsh complex of the Chesapeake Bay revealed large spatial gradients in water optical properties and concentrations of materials, associated with exchanges of dissolved and particulate organic compounds, DIC, and $\mathrm{CO}_{2}$ between the marsh, the estuary and the atmosphere.

The change in salinity along each individual transect (and particularly within the Kirkpatrick marsh) was relatively small, reflecting limited input of freshwater from the Muddy Creek watershed during our study (Fig. 2A,B). Larger salinity changes were observed among the transects, reflecting temporal variability in environmental parameters such as rainfall and temperature. Because salinity affects rates of alkalinitygenerating processes such as sulfate reduction (Chen \& Wang 1999), these changes in salinity have the potential to affect the dynamics of marsh DIC cycling (Fig. 2C,D). However, consistently lower $\mathrm{pH}$ values ( 6.8) in the tidal creek draining Kirkpatrick marsh as compared to the estuary $(\sim 7.8)$, and the relatively small temporal variability observed in $\mathrm{pH}$, indicate that such effects are small compared to the input of more acidic water from the marshes to the estuary, possibly associated with the higher concentrations of DOC, which are rich in weak organic acids, and supersaturated $p \mathrm{CO}_{2}$. Indeed, the temporal variability in environmental parameters was not reflected in the DOC or CDOM measurements.

\section{Marsh influence on dissolved and particulate organic carbon dynamics}

Organic carbon dynamics in the eutrophic Rhode River subestuary are affected by many sources, including seasonal in situ biological activity, atmospheric deposition, and inputs from Muddy Creek, groundwater draining from the watershed, and marshes (Jordan \& Correll 1991, Gallegos et al. 2005). Continuous monitoring of tidal exchanges in the Kirkpatrick marsh over a 3 yr period (1987 to 1989) by Jordan \& Correll (1991) revealed a net export of total organic carbon 
(TOC, including both dissolved and particulate) to the estuary of $\sim 50 \mathrm{~g} \mathrm{~m}^{-2} \mathrm{yr}^{-1}$. About $40 \%$ of this export was attributed to atmospheric and watershed inputs to the marsh, with the rest originating from the marsh itself. Due to the sampling methods used, the authors were not able to distinguish between particulate organic carbon (POC) and DOC fractions. Subsequent work at the site during 2004 and 2005 by Tzortziou et al. (2008) focused on the DOC component and revealed a net DOC export from the marsh to estuary that occurred consistently during seasons of both low and high marsh plant productivity. Tzortziou et al. reported that, during their sampling in July 2004, water draining the marshes was more than 2-fold enriched in DOC relative to the estuary, with DOC concentrations in the range of 10.9 to $13.5 \mathrm{mg} \mathrm{l}^{-1}$. These values are in good agreement with our results at the marsh end-member of our transect, despite the fact that sampling was performed in different years (Fig. 3A). Similarly, our DOC values for the estuarine end-member of Transect A are consistent with results from a 2 yr data set collected from 2004 to 2005 (T. E. Jordan unpubl. data), showing that average DOC concentration in the estuarine waters close to our Site A8 (Fig. 1) was about $4 \mathrm{mg} \mathrm{l}^{-1}$ $(\mathrm{SD}=1.44)$.

Although most studied tidal marsh systems seem to act as sources of DOC (Nixon 1980, Childers et al. 2000), higher variability has been reported in the rates and direction of particle exchange between marsh and estuarine environments (Tobias \& Neubauer 2009). Our measurements revealed different patterns in the spatial gradients of DOC and algal biomass (chl a) in the Rhode River estuary. Although water draining from the Kirkpatrick marshes was clearly enriched in DOC, it was depleted in chl $a$, with concentrations in the marsh less than half those in the estuarine waters (Fig. 3D). Net import of chl a during tidal exchanges has been reported for other marsh systems, both in freshwater estuaries (Van Damme et al. 2009) and in coastal environments (Moll 1977). The trend of increasing phaeo $a$, produced by degradation of chl $a_{1}$ within the marsh tidal creek indicates that some chl $a$ decrease is due to loss processes within the marsh, such as grazing. Consistent with our results, Jordan et al. (1983) found that, on a yearly average, the highelevation marshes in the Rhode River subestuary tend to trap particulate matter and export dissolved nutrients. This release of dissolved nutrients from the marshes and surrounding watershed could influence biological activity in the adjacent Muddy Creek mudflat. Along our transects, chl a reached maximum values in the shallow waters above the Muddy Creek subtidal mudflat, with concentrations twice as large as those at the estuarine end-member (Fig. 3D) and more than 4 times higher than those in the vicinity of the
Kirkpatrick and Hog Island marshes (Fig. 5C). The role of the Muddy Creek subtidal mudflat as a sink for dissolved nutrients in the Rhode River subestuary was evidenced by measurements in Jordan et al. (1983). Similarly, measurements by Welsh (1980) in a New England salt marsh-mudflat ecosystem showed that the intertidal mudflat was primarily an area of trapping and removal of nutrients released from the marsh, due to uptake by geochemical or biological activity of the sediments and benthic communities. However, the close correlation of chl a with phaeo a within Muddy Creek suggests that the relative balance between production (growth) and loss (grazing, senescence) processes did not vary over the mudflat region. Other processes, including concentration of particles by convergent circulation patterns or resuspension of microphytobenthos, might also be responsible for the chl a peak we observed in the center of the Muddy Creek subtidal mudflat.

\section{Marsh influence on estuarine CDOM dynamics}

Even more pronounced than the effects on estuarine organic carbon fluxes was the influence of the marshes on estuarine water optical properties and CDOM dynamics (Fig. 3B,C). This is because the DOM exported from these tidal marshes is not only enriched in DOC but it is also characterized by a high content of highMW, aromatic-rich and strongly absorbing humic compounds relative to estuarine DOM (Tzortziou et al. 2008). The relatively strong correlations we found between DOC and CDOM absorption ( $\mathrm{R}=0.91$ ), as well as between DOC and fluorescence magnitude $(\mathrm{R}=0.92)$, suggest that CDOM could be used as a relatively good proxy for DOC concentrations in this system, allowing for automated and continuous monitoring of DOC fluxes using optical sensors. However, only about half of the observed range in $a_{\mathrm{CDOM}}(440)$ was due to variation in DOC concentration (Fig. 3A). The other half was due to parallel variation in the DOCspecific CDOM absorption along the estuarine gradient (Fig. 4A), associated with changes in the quality and relative amounts of DOM from different sources in this system. DOM in the Rhode River estuarine waters is a complex mixture of material derived from in situ biological activity and inputs from the local watershed and wetlands of Muddy Creek (Gallegos et al. 2005). CDOM exported from the Kirkpatrick marsh has been previously shown to be optically distinctive compared to this estuarine material, with relatively higher DOCspecific absorption, lower fluorescence per unit absorbance, and a relatively lower absorption spectral slope (Tzortziou et al. 2008). Our measurements along the north Muddy Creek shoreline further show that 
marsh-exported CDOM has a distinctive optical signature even compared to CDOM derived from other terrestrial sources (e.g. forest vegetation) in this system. Both $\mathrm{S}_{\mathrm{CDOM}}$ and F: $a_{\mathrm{CDOM}}$ (highly correlated for all measurements in our study; $\mathrm{R}=0.99$ ) were considerably lower in the water influenced by export from the Kirkpatrick and Hog Island marshes than in the water influenced by the forested shoreline at Fox Point (Transect D, Fig. 6). The 2 quantities have been proposed as tracers of DOM molecular size, both typically being lower for higher-MW humic substances (Stewart \& Wetzel 1980, 1981, Markager \& Vincent 2000, Twardowski et al. 2004, Belzile \& Guo 2006, Tzortziou et al. 2008). The slope ratio, $S_{R}$, has also been found to be inversely related to DOM MW over a broad range of size-fractionated natural organic matter samples (Helms et al. 2008). The lower $S_{R}$ values we measured for marsh-exported relative to estuarine CDOM (Fig. 4C) are consistent with our $\mathrm{S}_{\mathrm{CDOM}}$ and $\mathrm{F}: \mathrm{a}_{\mathrm{CDOM}}$ results and further indicate that water draining off the marshes is enriched in relatively high-MW, humic DOC. Steep optical gradients, associated with these differences in CDOM properties and with composition of the marshes and other sources of CDOM in this system, were observed within the first 300 to $400 \mathrm{~m}$ from the marsh. However, the marsh optical 'signature' was distinguishable from the regional estuarine background over a distance of more than $1 \mathrm{~km}$ into the river (Fig. 4), suggesting that marsh-exported CDOM influences estuarine optical (and thus biogeochemical) variability considerably beyond the marsh-estuary interface.

Comparisons of our measurements of CDOM spectral properties with those of previous studies in the same waters allow us to assess seasonal and year-toyear variability in the quality of marsh-exported material. Measurements over a 3 yr period covering the months of April to October (from 1999 to 2001; C. L. Gallegos unpubl. data) showed that average $\mathrm{S}_{\mathrm{CDOM}}$ close to our Site A8 was $0.0177 \mathrm{~nm}^{-1}(\mathrm{SD}=0.0012)$ compared to our $\mathrm{S}_{\mathrm{CDOM}}$ of $0.0182 \mathrm{~nm}^{-1}$. Our results for $\mathrm{S}_{\mathrm{CDOM}}$ at the marsh end-member of our transects $\left(0.0152 \mathrm{~nm}^{-1}, \mathrm{SD}=0.0003\right)$ are consistent with Tzortziou et al. (2008), who found that average $S_{\mathrm{CDOM}}$ at the marsh shoreline and during low tide was $0.0149 \mathrm{~nm}^{-1}$ $(\mathrm{SD}=0.0005)$. The low standard deviation and the strong agreement between the $\mathrm{S}_{\mathrm{CDOM}}$ values reported in the 2 studies suggest that the quality and composition of CDOM exported from the Kirkpatrick marshes remain remarkably consistent throughout the year, as well as from year to year. The low seasonal variability in marsh CDOM export occurs despite dramatic seasonal variation in marsh plant activity, indicating that marsh soils play a critical role in regulating tidal exchanges, acting as reactors that process plant pro- duction into DOC and as reservoirs that release it at a relatively constant rate. Pore waters have been suggested as a major source of CDOM to adjacent estuaries in mangrove environments (Tremblay et al. 2007) and in Southern Californian salt marshes (Clark et al. 2008).

\section{Marsh export of DIC}

Most research on tidal marsh outwelling has focused on nutrient or organic carbon exchange, with relatively little attention to inorganic carbon fluxes. A growing body of research shows that $p \mathrm{CO}_{2}, \mathrm{DIC}$ and alkalinity concentrations in estuaries often exceed those expected from the conservative mixing of coastal and riverine sources (Cai et al. 2000, Raymond et al. 2000, Cai et al. 2003, Jiang et al. 2008). Tidal marshes have been proposed as a quantitatively important source of this 'excess' inorganic carbon (Cai \& Wang 1998), but mineralization of organic carbon (Frankignoulle et al. 1998) and in situ anaerobic sediment respiration (Raymond et al. 2000) have also been proposed as dominant sources of inorganic carbon. These sources are not mutually exclusive, but the evidence supporting them, such as mass balance calculations, is largely circumstantial. More direct evidence for marsh export of DIC was provided by Neubauer \& Anderson (2003), who observed that the DIC concentration in a creek draining a tidal freshwater marsh was up to 5-fold higher at low tide than at high tide, suggesting that export of marsh-derived DIC could explain $47 \%$ of excess DIC production in the York River, USA. In the present study, $p \mathrm{CO}_{2}$ and DIC concentration increased dramatically with proximity to the marsh (Fig. 2), providing further direct evidence that tidal wetlands are a source of inorganic carbon. The relationship of $p \mathrm{CO}_{2}$ and DIC concentration to marsh proximity is not explained by conservative mixing because salinity did not vary appreciably along Transects B and C, and salinity varied inversely to DIC along Transect A. The rapid decline in $p \mathrm{CO}_{2}$ and DIC concentration with increasing distance from the marsh was probably due in large part to mixing, as the DOC data would suggest. In addition, since the $p \mathrm{CO}_{2}$ values are much above equilibrium values, $\mathrm{CO}_{2}$ was degassing to the atmosphere with a concomitant shift in the carbonate system equilibrium.

\section{Mixing and degradation processes}

Our measurements of CDOM properties from the Muddy Creek mudflat to the Rhode River estuarine end-member showed conservative mixing based on 
salinity along that section of the transect (Fig. 7A,B). Good agreement was also found between our measurements and the theoretical line representing conservative mixing along the watershed shoreline of Muddy Greek (Fig. 7C,D). These results suggest that a portion of the marsh DOM exported to the Muddy Creek mudflat consists of relatively refractory compounds that through conservative mixing become part of the 'background' estuarine DOM, and that the effect of marshes on estuarine water chemistry persists at much larger spatial scales in the estuary than our transects could demonstrate (Cai et al. 2003).

Previous studies showing that tidal marshes are significant sources of relatively refractory lignin-rich humic substances to nearshore and continental shelf waters (e.g. Moran et al. 1991, Moran \& Hodson 1994) are consistent with these results. However, when considering the full extent of the estuarine gradient from the marshland to the estuary (solid line in Fig. 7A,B), both DOC and CDOM were lower, while $\mathrm{S}_{\mathrm{CDOM}}$ and $\mathrm{F}: a_{\mathrm{CDOM}}$ were higher, as compared to conservative mixing between the 2 end-members. This non-conservative behavior of DOC and CDOM with salinity could be the result of intense processing of the relatively labile marsh-DOM components, resulting in both removal (DOC losses) and transformation (CDOM spectral changes) of marsh-exported material within a few hundred meters of the marsh. Consistent with this interpretation, previous studies have shown that marsh-exported CDOM has relatively strong photoreactivity and thus strong susceptibility to photochemical and subsequent microbial degradation as compared to the less photoreactive (and probably already photobleached) estuarine CDOM (Tzortziou et al. 2007). The apparent non-conservative behavior of DOM along Transect A could also be due to mixing with a third source of DOM from upstream Muddy Creek. Muddy Creek input has a salinity similar to that of water draining the marshes, but different CDOM characteristics. Measurements by Tzortziou et al. (2007) on samples collected in August 2004 showed that material from upstream Muddy Creek is characterized by relatively lower $a^{*}{ }_{\mathrm{CDOM}}$, higher $\mathrm{F}: \mathrm{a}_{\mathrm{CDOM}}$, and higher $\mathrm{S}_{\mathrm{CDOM}}$ $\left(0.0168 \mathrm{~nm}^{-1}\right)$ as compared to marsh-derived CDOMresults that are all indicative of lower-MW compounds. The $\mathrm{S}_{\mathrm{CDOM}}$ value of $0.0168 \mathrm{~nm}^{-1}$ for Muddy Creek CDOM would be consistent with the value of $0.0172 \mathrm{~nm}^{-1}$ that we derived by extrapolation of the theoretical dilution line representing conservative mixing between the terrestrial/marsh mixture and the estuarine end-member (dotted line in Fig. 7A,B).

The observed increase in $S_{R}$ along the full extent of the Rhode River estuarine gradient is consistent both with mixing with Muddy Creek CDOM (of lower MW and thus higher $\mathrm{S}_{\mathrm{R}}$ ) and with photochemical transfor- mation of marsh-derived CDOM. In agreement with Helms et al. (2008), preliminary experiments by our group (unpubl. data) show that $\mathrm{S}_{\mathrm{R}}$ is a good indicator of CDOM photochemical versus microbial processing. In all our experiments using marsh-derived and estuarine CDOM, microbial alteration resulted in a decrease in $\mathrm{S}_{\mathrm{R}}$ while photochemical degradation had the opposite effect, resulting in $S_{R}$ increases. Thus, our measurements along the full extent of the Rhode River estuarine gradient would be consistent with photodegradation being the dominant transformation process of the labile marsh-DOM components over short time-scales, while microbial degradation seems to be more important for mineralization and at larger and longer scales.

Using a box model based on watershed inputs and chloride distributions, Jordan et al. (1991) estimated that a conservative tracer has an $\sim 2.5 \mathrm{~d}$ half-life in the 'upper estuary' of the Rhode River under low-flow, summertime conditions (discharge $<5000 \mathrm{~m}^{3} \mathrm{~d}^{-1}$ ). This estimate applies to exchange between Muddy Creek upstream of our Site A8 and the lower estuary. This corresponds to an average exchange with the lower estuary of $5.1 \times 10^{4} \mathrm{~m}^{3} \mathrm{~d}^{-1}$. These results indicate that the retention time in this system is long enough that CDOM levels would be expected to be much higher than observed in our transects if conservative mixing was the only process influencing changes in concentration. Rather, the observed gradients seem to be the result of a combination of mixing, photochemical degradation, and subsequent microbial degradation. Detailed modeling of these processes would be required to better quantify their relative importance in this system.

The Chesapeake Bay estuary and its watershed have been subject to considerable anthropogenic pressure over the past century, associated with increased human population. Large areas of tidal wetlands continue to be damaged or lost due to development, filling, dredging and other anthropogenic disturbances, while projected global sea level rise due to climate change poses a significant threat for coastal marsh ecosystems. Understanding the influence of tidal marshes on estuarine nutrient dynamics and biogeochemical gradients has become increasingly important for projecting the influence of both continued disturbance and restoration efforts on estuarine ecosystems. The high marshes in the Rhode River subestuary are representative of brackish high marshes of mid-Atlantic North America (Jordan \& Correll 1991). Our results illustrate that these tidal marshes are a major source of DOC, DIC and $p \mathrm{CO}_{2}$ to the adjacent estuary and atmosphere, and may trap algae and probably other suspended particulate matter while they release high-MW, aromatic, humic-rich, colored dissolved organic compounds into the estuary through tidal flushing. Despite the possible 
role of the adjacent subtidal mudflat as a sink for some of the dissolved nutrients released from the marshes, the marsh 'optical signature' was distinguishable from the regional estuarine background over a distance of more than $1 \mathrm{~km}$ into the river, suggesting that tidal marsh outwelling of DOC exerts a strong influence on estuarine optical, biological and biogeochemical variability considerably beyond the marsh-estuary interface.

Acknowledgements. This work was supported by National Science Foundation Grants DEB: 0742185 and DEB: 0742195. Additional funding was provided by the National Aeronautics and Space Administration, Ocean Biology and Biogeochemistry Program, the Smithsonian Institution and the National Science Foundation-Research Experience for Undergraduates (NSF-REU) Internship Program. We thank J. Duls and S. Hedrick for assistance in the field and laboratory.

\section{LITERATURE CITED}

Arar EJ, Collins GB (1997) Method 445.0, in vitro determination of chlorophyll $a$ and pheophytin $a$ in marine and freshwater algae by fluorescence. In: Methods for the determination of chemical substances in marine and estuarine environmental matrices, EPA/600/R-97/072, 2nd edn. National Exposure Research Laboratory, Office of Research and Development, USEPA, Cincinnati, $\mathrm{OH}_{\text {, }}$ p 1-22

Belzile C, Guo LD (2006) Optical properties of low molecular weight and colloidal organic matter: application of the ultrafiltration permeation model to DOM absorption and fluorescence. Mar Chem 98:183-196

Belzile C, Gibson JAE, Vincent WF (2002) Colored dissolved organic matter and dissolved organic carbon exclusion from lake ice: implications for irradiance transmission and carbon cycling. Limnol Oceanogr 47:1283-1293

Borges A (2005) Do we have enough pieces of the jigsaw to integrate $\mathrm{CO}_{2}$ fluxes in the coastal ocean? Estuaries 28:3-27

Cai W, Wang Y (1998) The chemistry, fluxes, and sources of carbon dioxide in the estuarine waters of the Satilla and Altamaha Rivers, Georgia. Limnol Oceanogr 43:657-668

Cai WJ, Pomeroy LR, Moran MA, Wang Y (1999) Oxygen and carbon dioxide mass balance for the estuarine-intertidal marsh complex of five rivers in the southeastern U.S. Limnol Oceanogr 44:639-649

> Cai WJ, Wiebe WJ, Wang Y, Sheldon JE (2000) Intertidal marsh as a source of dissolved inorganic carbon and a sink of nitrate in the Satilla River-estuarine complex in the southeastern U.S. Limnol Oceanogr 45:1743-1752

> Cai WJ, Wang ZA, Wang Y (2003) The role of marsh-dominated heterotrophic continental margins in transport of $\mathrm{CO}_{2}$ between the atmosphere, the land-sea interface and the ocean. Geophys Res Lett 30:1849 doi:10.1029/2003GL017633

Carder KL, Steward RG, Harvey GR, Ortner PB (1989) Marine humic and fulvic acids: their effects on remote sensing of ocean chlorophyll. Limnol Oceanogr 34:68-81

Cestti R, Srivastava J, Jung S (2003) Agriculture non-point source pollution control: good management practices the Chesapeake Bay experience. World Bank Working Paper No 7, The World Bank

Chen CTA, Wang SL (1999) Carbon, alkalinity and nutrient budgets on the East China Sea continental shelf. J Geophys Res 104:20675-20686

Childers DL, Cofer-Shabica S, Nakashima L (1993) Spatial and temporal variability in marsh-water column interactions in a southeastern USA salt marsh estuary. Mar Ecol Prog Ser 95:25-38

Childers DL, Day JW Jr, McKellar HN Jr (2000) Twenty more years of marsh and estuarine flux studies: revisiting Nixon (1980). In: Weinstein M, Kreeger DA (eds) Concepts and controversies in tidal marsh ecology. Kluwer Academic Publishing, Dordrecht, p 391-423

Clark CD, Litz LP, Grant SB (2008) Saltmarshes as a source of chromophoric dissolved organic matter (CDOM) to Southern California coastal waters. Limnol Oceanogr 53: 1923-1933

Dame RF (1994) The net flux of materials between marshestuarine systems and the sea: the Atlantic coast of the United States. In: Mitsch WJ (ed) Global wetlands: Old World and New. Elsevier, Amsterdam, p 295-305

Dame RF, Spurrier JD, Williams TM, Kjerfve B and others (1991) Annual material processing by a salt marshestuarine basin in South Carolina, USA. Mar Ecol Prog Ser 72:153-166

Dankers N, Binsbergen M, Zegers K, Laane R, Vanderloeff MR (1984) Transportation of water, particulate and dissolved organic and inorganic matter between a salt marsh and the Ems-Dollard estuary, The Netherlands. Estuar Coast Shelf Sci 19:143-165

Ferrari GM, Mingazzini M (1995) Synchronous fluorescence spectra of dissolved organic matter (DOM) of algal origin in marine coastal waters. Mar Ecol Prog Ser 125:305-315

Frankignoulle M, Abril G, Borges A, Bourge I and others (1998) Carbon dioxide emission from European estuaries. Science 282:434-436

Gallegos CL, Jordan TE, Hines AH, Weller DE (2005) Temporal variability of optical properties in a shallow, eutrophic estuary: seasonal and interannual variability. Estuar Coast Shelf Sci 64:156-170

Helms JR, Stubbins A, Ritchie JD, Minor EC, Kieber DJ, Mopper K (2008) Absorption spectral slopes and slope ratios as indicators of molecular weight, source, and photobleaching of chromophoric dissolved organic matter. Limnol Oceanogr 53:955-969

Jiang LQ, Cai WJ, Wanninkhof R, Wang Y, Luger H (2008) Air-sea $\mathrm{CO}_{2}$ fluxes on the US South Atlantic Bight: spatial and seasonal variability. J Geophys Res 113:C07019 doi: 10.1029/2007JC004366

Jordan TE, Correll DL (1991) Continuous automated sampling of tidal exchanges of nutrients by brackish marshes. Estuar Coast Shelf Sci 32:527-545

Jordan TE, Correll DL, Whigham DF (1983) Nutrient flux in the Rhode River: tidal exchange of nutrients by brackish marshes. Estuar Coast Shelf Sci 17:651-667

Jordan TE, Pierce JW, Correll DL (1986) Flux of particulate matter in the tidal marshes and subtidal shallows of the Rhode River estuary. Estuaries 9:310-319

Jordan TE, Correll DL, Miklas J, Weller DE (1991) Nutrients and chlorophyll at the interface of a watershed and an estuary. Limnol Oceanogr 36:251-267

Kalber FA Jr (1959) A hypothesis on the role of tide-marshes in estuarine productivity. Estuarine Bull 4:3

Kirk JTO (1994) Light and photosynthesis in aquatic ecosystems. Cambridge University Press, Cambridge

Lewis E, Wallace DWR (1998) Program developed for $\mathrm{CO}_{2}$ system calculations. ORNL/CDIAC-105. Oak Ridge National Laboratory, US Department of Energy, Oak Ridge, TN 
Lloyd JBF (1971) Synchronized excitation of fluorescence emission spectra. Nature Phys Sci 231:64-65

Markager S, Vincent WF (2000) Spectral light attenuation and the absorption of UV and blue light in natural waters. Limnol Oceanogr 45:642-650

McKnight DM, Boyer EW, Westerhoff PK, Doran PT, Kulbe T, Andersen DT (2001) Spectrofluorometric characterization of dissolved organic matter for indication of precursor organic material and aromaticity. Limnol Oceanogr 46 38-48

Megonigal JP, Neubauer SC (2009) Biogeochemistry of tidal freshwater wetlands. In: Perillo GME, Wolanski E, Cahoon D, Brinson M (eds) Coastal wetlands: an integrated ecosystem approach. Elsevier, Amsterdam, p 535-563

Mencken HL (1940) Happy days, Vol 1. Alfred A. Knopf, New York, NY

Moll RA (1977) Phytoplankton in a temperate-zone salt marsh: net production and exchanges with coastal waters. Mar Biol 42:109-118

Moran MA, Hodson RE (1994) Dissolved humic substances of vascular plant origin in a coastal marine environment. Limnol Oceanogr 39:762-771

Moran MA, Wicks RJ, Hodson RE (1991) Export of dissolved organic matter from a mangrove swamp ecosystem: evidence from natural fluorescence, dissolved lignin phenols, and bacterial secondary production. Mar Ecol Prog Ser 76:175-184

Neubauer SC, Anderson IC (2003) Transport of dissolved inorganic carbon from a tidal freshwater marsh to the York River estuary. Limnol Oceanogr 48:299-307

Nixon SW (1980) Between coastal marshes and coastal waters: a review of twenty years of speculation and research on the role of salt marshes in estuarine productivity and water chemistry. In: Hamilton R, MacDonald KB (eds) Estuarine and wetland processes. Plenum Press, New York, NY, p 437-525

Odum EP (1961) The role of tidal marshes in estuarine production. NY State Conserv 15:12-15

Pelletier G, Lewis E, Wallace D (2007) CO2sys.xls: a calculator for the $\mathrm{CO}_{2}$ system in seawater for Microsoft Excel/ VBA. Washington State Department of Ecology, Olympia, WA. Available at: www.ecy.wa.gov/programs/eap/ models/co2sys_ver14.zip

Peterson B, Fry B, Hullar M, Saupe S, Wright R (1994) The distribution and stable carbon isotopic composition of dissolved organic carbon in estuaries. Estuaries 17:111-121

Raymond PA, Bauer JE, Cole JJ (2000) Atmospheric $\mathrm{CO}_{2}$ evasion, dissolved inorganic carbon production, and net heterotrophy in the York River estuary. Limnol Oceanogr 45:1707-1717

Sloey WE, Spangler RL, Fetter CW Jr (1978) Management of freshwater wetlands for nutrient assimilation. In: Good RE, Whigham DF, Simpson RL (eds) Freshwater wetlands: ecological processes and management potential. Acade-

Editorial responsibility: Ronald Kiene,

Mobile, Alabama, USA mic Press, New York, NY, p 321-340

Stewart AJ, Wetzel RG (1980) Fluorescence:absorbance ratios: a molecular-weight tracer of dissolved organic matter. Limnol Oceanogr 25:559-564

Stewart AJ, Wetzel RG (1981) Asymmetrical relationships between fluorescence, absorbance, and dissolved organic carbon. Limnol Oceanogr 26:590-597

Teal JM (1962) Energy flow in the salt marsh ecosystem of Georgia. Ecology 43:614-624

Tobias C, Neubauer SC (2009). Salt marsh biogeochemistry: an overview. In: Perillo GME Wolanski E, Cahoon D, Brinson $\mathrm{M}$ (eds) Coastal wetlands: an integrated ecosystem approach. Elsevier, Amsterdam, p 445-493

Tremblay LB, Dittmar T, Marshall AG, Cooper WJ, Cooper WT (2007) Molecular characterization of dissolved organic matter in a North Brazilian mangrove porewater and mangrove-fringed estuaries by ultrahigh resolution Fourier transform-ion cyclotron resonance mass spectrometry and excitation/emission spectroscopy. Mar Chem 105:15-29

Twardowski MS, Boss E, Sullivan JM, Donaghay PL (2004) Modeling the spectral shape of absorption by chromophoric dissolved organic matter. Mar Chem 89:69-88

Tzortziou M, Osburn CL, Neale PJ (2007) Photobleaching of dissolved organic material from a tidal marsh-estuarine system of the Chesapeake Bay. Photochem Photobiol 83: $782-792$

Tzortziou M, Neale PJ, Osburn CL, Megonigal JP, Maie N, Jaffe R (2008) Tidal marshes as a source of optically and chemically distinctive colored dissolved organic matter in the Chesapeake Bay. Limnol Oceanogr 53:148-159

Valiela I, Teal JM, Sass W (1973) Nutrient retention in salt marsh plots experimentally fertilized with sewage sludge. Estuar Coast Mar Sci 1:261-269

Van Damme S, Dehairs F, Tackx M, Beauchard O and others (2009) Tidal exchange between a freshwater tidal marsh and an impacted estuary: the Scheldt estuary, Belgium. Estuar Coast Shelf Sci 85:197-207

Wang ZA, Cai WJ (2004) Carbon dioxide degassing and inorganic carbon export from a marsh-dominated estuary (the Duplin River): a marsh $\mathrm{CO}_{2}$ pump. Limnol Oceanogr 49: 341-354

Welsh BL (1980) Comparative nutrient dynamics of a marshmudflat ecosystem. Estuar Coast Mar Sci 10:143-164

Whiting G, McKellar H, Spurrier J, Wolaver T (1989) Nitrogen exchange between a portion of vegetated salt marsh and the adjoining creek. Limnol Oceanogr 34:463-473

Wiegert RG, Christian RR, Wetzel RL (1981) A model view of the marsh. In: Pomeroy LR, Wiegert RG (eds) The ecology of a salt marsh. Springer-Verlag, New York, NY, p 183-218

Woodwell GM, Whitney DE, Hall CAS, Houghton RA (1977) The Flax Pond ecosystem study: exchanges of carbon in water between a salt marsh and Long Island Sound. Limnol Oceanogr 22:833-838

Submitted: July 10, 2010; Accepted: December 28, 2010

Proofs received from author(s): March 8, 2011 